\title{
Influence of quality of life on the state and development of human capital in Latvia
}

\author{
Zhanna Tsaurkubule
}

\begin{abstract}
Currently, the essence and forms of interrelation between human capital and quality of life are still insufficiently studied. Therefore, there is a need for defining general components of these categories and areas, where human capital interacts with quality of life. Today, Latvia has been developing in difficult conditions: the population is decreasing, emigration is growing, possibilities of employment are limited, and the income of residents is decreasing. All these factors reduce quality of life for the population and lead to the loss of human resources in the country. The existence of a problem stemming from the relationship between quality of life and human capital establishes the relevance of the research and determines its aim. The main contradiction is between the external positioning of the state as a country successfully overcoming crisis and the growth of internal crisis in the state, leading to the further impoverishment of the population, leading to an increased emigration of the working population of Latvia. The main research question is as follows: how to preserve human resources in the state? Based on an analysis of post-crisis socio-economic processes taking place in the society, recommendations are made to improve the socio-economic policy in ways that improve the welfare of the population of Latvia.
\end{abstract}

KEY WORDS: $\quad$ human capital; quality of life; welfare; poverty

JEL Classification: J24, O15, P46

${ }^{1}$ Baltic Psychology and Management University College, Latvia

\section{Introduction}

The current socio-economic situation in Europe and the world, which is suffering a global financial and economic crisis, reveals a number of problems and tasks that must be placed on the agenda with great urgency. Particular concern is caused by a deterioration in the general population's living conditions and, in a broader sense, the quality of life and the health of separate

Correspondence concerning this article should be addressed to: Zhanna Tsaurkubule, Baltic Psychology and Management University College, Lomonosova str. 4, Riga, Latvia, LV-1003. E-mail: zhannac@inbox.lv categories and the population groups facing socioeconomic problems.

Finding a solution to the above-mentioned problems for Latvia is critical, as currently, the economy is in both structural crisis and cyclical crisis, as well as difficult political and social changes take place in society.

In the modern conditions of Latvia's development against continuous financial and economic crisis and increasing emigration of Latvian natural citizens to other European Union countries and other countries around the world, the problem of preserving human capital has become more and more real because the developed human capital is the most important factor 
in the country's competitive advantage in the modern condition of the world's economy. Human capital is the basis of many phenomena, including the stimulation of economic growth. Thus, an increase in human capital by one percent results in an increase in the rate of GDP growth per capita by 1-3\%. (Sianesi \&Van Reenen, 2003)

In this study, human capital is considered not as an end in itself, but as a resource to be used for the social and economic development of a country. The relevance of research into this problem is due to both the objective needs in the present stage of world social and economic development as well as the specifics of the current situation in Latvia, which requires decision makers to ensure sustainable economic growth along with the achievement of a higher level of welfare.

Aim of the research - This research aims to study the influence of human well-being (and, as a result, quality of life) on the development and maintenance of human capital at the macro and micro levels and, on this basis, to develop recommendations for improving the economic and social policies in support of welfare.

\section{Research objectives:}

- to analyze and summarize the features of the current stage of Latvian social and economic development from the position of well-being value change;

- to reveal how welfare influences human capital and to determine its importance both to achieving economic growth and to increasing the competitiveness of employees and companies;

- to justify the need for social and economic policy formation in Latvia to take into account the impact of quality of life and status of the population on human capital saving.

The subject of this research is quality of life's influence on human capital. The research object is social and economic relations in Latvia and the EU. The theoretical basis of this research was made by ideas and concepts presented in classic and contemporary works of scientists on the problems of human capital, welfare, social and labor relations, labor, and social behavior. An informational basis was made through the results of studies, inquiries, and surveys of the labor and social behavior, as well as statistics. We used scientific methods, such as systemic and situational approach and structural and comparative analysis.

\section{Development of human capital theory}

In the late 1950s and early 1960s, the works of Shultz (1971), Becker (1993), Tnurow (1970) were published on human capital theory, and these are now considered classics and have generally shaped its present form. In 1971 Shultz (1971) first offered the term "human capital", especially emphasizing the productive character of human capital, its ability to accumulate and to reproduce on a renewable basis. The development of human capital theory continued in studies by Mincer (1975) and Ben-Porath (1967), Krochmal and Staniewski (2010), which was devoted to economically justifying an investment in people. Human capital was understood as the supply of knowledge, skills and qualifications of specific persons, groups of persons and the entire society defining their ability to work, adapt to change, and also act creatively (Białowolski et al., 2011). It is especially worth noting three main components of human capital selected with T. Shultz, which to some extent embodies the value of long-time investments in people, including the following (Solovov, 2009):

- The individual qualities used in operation, such as intelligence, energy, overall positive attitude, reliability, and responsibility.

- Learnability, general and special abilities, imagination, creativity, ingenuity, and knowledge.

- The motivation to share information and knowledge in the context of command spirit and orientation to joint goals.

The current strategy of most developed countries is now constructed with post-industrial development factors. It is well-known that human capital plays an important strategic role among internal factors in the development of post-industrial society, both at the macro and micro levels. In particular, at the macro-level, human capital is formed through investments in health care, culture, the improvement of people's living conditions, training in accordance with the future demand of the labor market, and opportunities for fair competition. In turn, the development of human capital at the micro level is shown as the main source of competitiveness, continu- 

- environmental aspects (satisfaction with the situation in the country, the place of residence, the level of safety in the place of residence),

- health-related aspects (satisfaction with one's health condition), and other aspects, related to self-assessment (satisfaction with one's own achievements, prospects for the future, educational level, the way of spending leisure time, work). (Czapiński, Sułek Szumlicz, 2011)

Quality of life has two aspects: objective and subjective. The criterion for an objective assessment of the quality of life are the academic standards of people's needs and interests, in relation to which it is possible to objectively judge the extent of these needs and interests. On the other hand, the needs and interests of people are individual and only the individuals can evaluate the level of its satisfaction. They aren't fixed by any statistical values and practically exist only in people's minds and, therefore, in their personal opinions and assessments.

Thus, the assessment of quality of life appears in two forms:

1. Satisfaction level of research-based needs and interests;

2. Satisfaction with the quality of life of the people themselves.

\section{Quality of life and scale of life.}

Quality of life is not identical to a scale of life, including the most sophisticated forms of determination (for example, the living standards), because various economic measures of income are only one of the many (usually not less than 5) criteria for quality of life. Quality of life is an extremely broad, multi-faceted concept, incomparably greater than the "scale of life."

The scale of life considers only the level of material well-being - that is, the degree to which people's material needs are satisfied - and this material wellbeing - or rather, the average standard of living in the country - is displayed through indicators such as GDP per capita. However, the concept "quality of life" also includes "intangible" or, it might be better said, "non-cash" aspects of people's lives not expressed in and determined solely by money: their health and life expectancy, freedom from stress, the ability to enjoy recreation and leisure, cultural development and self- fulfillment, access to knowledge, and other riches of spiritual culture, etc.

Clearly, the objective of characterizing the quality of life of the citizens of a country is very difficult. This is because quality of life is an extremely complex and multifaceted concept, and it cannot be expressed in dollars or euros. It is necessary to use some type of integral index; nevertheless, the results obtained with the help of this index will always be incomplete and controversial. Thus, the scale of living (or welfare) and quality of life are still different and should not be conflated.

\section{Indicators of quality of life.}

Among integral, generalizing indicators of quality of life belongs the human development index, an index of the intellectual potential of society, human capital per capita, and the rate of population viability. Thus, the most important and most frequently cited indicator is the Human Development Index (HDI) economic index, developed in 1990 by Pakistani Mahbub ul Haq and Indian Amartya Sen and used by the UN to characterize the quality of life in different countries.

Since 1993, the UN has published an annual report on human development, which is calculated on the basis of GDP per capita, education, and life expectancy. Notably, the data in the UN report are delayed by 2 years: For example, the report for 2013 contains data for 2011, etc. (Human Development Report, 2013). According to the latest data, the five most successful countries include Norway, Australia, the United States, Netherlands and Germany. In total, 47 states were placed in a subgroup of countries with the highest level of development.

When designing synthetic indicators of the quality of life, Czapiński (2011b) endeavored to strike a balance between objective and subjective indicators, as well as to take the widest possible spectrum of various aspects into account. J. Czapiński distinguished eight dimensions assumed to cover independent content areas, which served to build up a general synthetic indicator of the quality of life:

- social capital - activity for the benefit of the local community, participation in self-government elections, participation in non-obligatory meetings, positive attitude towards democracy, membership in organizations and serving functions in them; 
- psychological well-being - sense of happiness, assessment of life as a whole, incidence of mental depression symptoms, assessment of the past year;

- physical well-being - incidence of somatic symptoms, serious disease in the past year, degree of disability, intensity of health-related stress;

- social well-being - lack of the feeling of loneliness, a sense of being loved and respected, a number of friends;

- civilization level - educational level, ownership of modern communication devices and familiarity with them, active command of foreign languages, driving license;

- material well-being - household income per equivalent unit, number of goods and appliances owned, ranging from automatic washing-machine to a motorboat or summer house (excluding appliances included in the civilization level indicator);

- stress in life - a sum of six categories of stress measured by experiences related to finance, work, liaison with public administration offices, bringing up children, the marriage relationship, environmental protection (home and surroundings);

- pathology - alcohol abuse and drug use, smoking, consulting a psychiatrist or psychologist, being a criminal or victim of crime (burglary, assault, and theft). (Czapiński, 2011b)

\section{Life quality of the Latvian population.}

Latvia also was placed by U.N. experts into a subgroup of the countries with very high level of development. Our country took 44th place in the overall ranking. While Lithuania ranked 41th, Estonia was in 33th place. By comparison, the average life expectancy in Norway is 81.3 years, while in Latvia it is 73.6 years. GDP per capita in Norway amounted to 48,688 dollars; in Latvia, it was 14,724 dollars.

The welfare of people in Latvia is in 47 th place in the world, but in comparison with other European countries, Latvia is in one of the last places. This was demonstrated by a study, Prosperity Index 2010, conducted by Legatum Institute, reports delfi.lv. The list takes into account not only material wealth but also the subjective satisfaction of human life (i.e., democracy, individual freedom and business opportunities).
Norway, Denmark and Finland were at the top of the list. The top ten includes Australia, New Zealand, Sweden, Canada, Switzerland, the Netherlands, and the U.S. Last place is taken by Zimbabwe, Pakistan, and the Central African Republic.

In Europe, Latvia is in 47th place, Romania in 51st, Belarus in 54th, Russia in 63rd, Ukraine in 69th, Macedonia in 72nd, Moldova in 86th, Lithuania in 42nd, and Estonia in 35th.

Another key indicator that comprehensively characterizes the level of social development achieved by a country is the quality-of-life index, developed by the Economist Intelligence Unit.

Authors of the annual ranking Quality of Life Index consider the living cost, infrastructure, economic indexes, freedom level, risk and safety, the state of the environment, health care, leisure and culture, and also climatic conditions. In the ranking of countries for the year 2010, Latvia came in 70th place, having lost five positions over 5 years (for 2005, it was in 65th) (International Living, 2010).

The components for standard of living are the specific requirements that are an integral part of the standard of living in general. Usually included in the component requirements are certain activities (production of food, medical care, education, etc.), which includes a variety of data related to the needs in the appropriate field during some period of time.

A set of components covers the full scope of human needs, and the degree of needs can be divided into four levels for the living population:

1. Wealth - enjoy the benefits that provide all-round development of a person;

2. The normal level - sustainable consumption, providing to a person the restoration of his physical and intellectual powers;

3. Indigence - consumption of goods on the level of saving working capacity as the lower border of labor power reproduction;

4. Poverty - the minimum acceptable set of goods and services whose consumption can only maintain the viability of the person.

Poverty imply a situation where a household does not have sufficient financial resources (both cash in the form of current income and income from previous periods and accumulated fixed assets) to satisfy its basic needs. (Czapiński, Panek, 2011; Panek, 2011). 
As for Latvia, the ill-conceived reform of its national economy has led not only to the impoverishing of socially vulnerable groups, such as the elderly, the disabled, and families with many children, but also to a depreciation of human capital, which remains unclaimed and does not act as a catalyst for economic growth. Therefore, high levels of poverty and unemployment not only reduce the standard of living but also lead to underuse of economic potential and accumulated human capital. In combination with inflation, rapid growth of unemployment and a decline in wages and pensions have led to millions of people below the poverty line.

The main socio-economic indicators of living standards are real GDP per capita, incomes and expenditures, real wages, consumption of basic food products per capita, natural population growth and life expectancy, the proportion of budget expenditures for the social areas, and the use of free time.

Gross domestic product per capita is the main indicator of a change in the poverty level, due to the interaction of business, government and society.

According to Eurostat, the GDP per capita in Latvia is almost half as much as the European average and is six times lower than those of the richest regions in the EU. If we take the European average of $100 \%$, the conventional level of wealth in Latvia (in terms of population purchasing power) is $56 \%$ of the EU level (compared to Lithuania at $61 \%$ and Estonia at $68 \%$ ).

The level of inequality in income distribution is measured by the Lorenz curve. It shows how much the total income differs in terms of income segments of the population, resulting in a change from 0 to 1 of the Gini coefficient, which reflects the values of income concentration.

Calculations show that, in Europe, the rich are approximately 5 times richer than poor people in the EU, whereas in Latvia, they are by 7.3 times wealthier. The Lorenz curve is usually applied to the current distribution of income. However, if it is applied to the distribution of wealth (property), the results show a greater disparity.

Today, Latvia is the poorest country in the European Union: $40.4 \%$ of Latvian residents are at risk of poverty. There are no such proportions of the poor people in any other country of the European Union. This is evidenced by the published revised data from Eurostat
(Eurostat, 2011). In absolute terms, 573,000 people in poverty live in Latvia, or every fourth resident. If we take the European average of $100 \%$, the conventional level of wealth in Latvia (in terms of population purchasing power) is $56 \%$ of the EU level (compared to Lithuania at $61 \%$ and Estonia at $68 \%$ ).). On average, in the EU, $16.5 \%$, or 81 million people, are subject to the risk of poverty.

According to the Ministry of Welfare, currently in Latvia, approximately $8 \%$ of people are poor, the middle class is rapidly reducing, and unemployment is rising. The number of poor in Riga increased last year by $29 \%$ (In Riga, the number of poor people has been growing, 2011).

Poverty, malnutrition, poor health, and lack of education are closely linked, and in some cases organize a closed and vicious circle in the middle of which are poor families.

The trend of education development in the country is directly related to demographic factors of the Latvian market, as well as to the formation of human capital. Statistics show that in recent years the number of children receiving secondary education has continued to decline. This fact is directly related to the number of people who are getting higher education, which has been declining since 2008. Today, Latvia is in last place in the EU in terms of fertility, and according to demographic projections, in 40 years the population will be reduced by half. This fact is cited in a document by the European Parliament, which is sent to all EU member states. This dangerous tendency is widespread: by 2050, the average age of people in Europe will have increased by 10 years, approaching the 50 -year mark. However, if in other countries the demographic problem is solved at the governmental level, the Latvian government only talks about it. According to the CSO, in the past, the population of Latvia was 2.28 million people, or 13,300 less than in 2006. As before, the greatest impact was the imbalance between birth rates and mortality $(-10,800)$; however, last year, the country was obviously affected by emigration.

According to official figures, last year, 2,500 people left the country, predominantly young people (Mosyakin, 2012). In just 20 years of independence, approximately 210,000 people have left the country, or nearly every 13 th person among those that lived there in the early 1990s. 
Thus, against a background of declining birth rates, depopulation, and migration, the number of students enrolled in higher education in Latvia will reverse in subsequent years. This could lead to a halting of development in education and certain research areas and therefore have a negative impact on all other sectors of the economy.

This situation requires an elaborate system of measures aimed at developing education in Latvia, one of which, in particular, is connected to the state of medicine and public health in the country. The reduction in state funding of health care has led to a continuously decreasing number of births and an increase in the mortality rate. According to experts, the population of Latvia by 2040 will be reduced through natural causes alone by 40,000 , from the current population of around 2.2 million to 1.8 million. This condition may lead to a universally aging population and the total inability of the country to carry out its public functions.

As for the general state of health and medicine in Latvia, we have to admit that, as measured by the main indicators of public health, Latvia confidently takes last place among the group of countries that joined the $\mathrm{EU}$ in 2004. Latvian residents die at a rate that is 1.5- to 2-times higher than rates in developed Europe, and children up to one year die at an almost threetimes-higher rate more often. Moreover, male life expectancy is 10 years less than in Europe, and only half of the children younger than 14 years can be considered healthy. Especially troubling is the fact that in the last five years, no changes to improve the situation were observed. The picture is completed by epidemics of infectious diseases: episodes of child and intestinal infections, during which the incidence exceeds the European rate by ten times, the epidemic of sexually transmitted diseases (even among children) and AIDS (only registered incidence is by 10 times higher than European), the incidence of tuberculosis is higher by 10 times than that of Europe.

The problem is exacerbated by a chronic and widening health system crisis, which in its current form, does not correspond to the internal needs of the population, nor to European ideology and practice.

A study named "Trends in social and economic development of cities in Latvia," conducted at the request of the State Regional Development Agency, shows that only $49.35 \%$ of Latvian residents were satisfied with a quality of their life, which is less than half (State Regional Development Agency, 2008).

In summary, the current situation of more than half of Latvian residents creates large difficulties for the positive development of the economy of Latvia in the present and near future. The consequence of continuously deteriorating welfare is the loss of the country's human resources and, in the long term, the country's lack of strategic development potential.

The ability for Latvia to overcome this crisis is impossible without shifting the existing socio-economic policies and infrastructure of the Latvian national economy towards increasing the industrial and agricultural weight, as a basis for adding value and improving the performance of social infrastructure and societal development. This is needed to develop the concept of strategic development by defining priority sectors, which will be based on the economy of Latvia. The government's tactics, aimed at survival by consolidating the budget through reductions and cuts, must give way to thinking oriented towards future development.

In the long run, a strategy for state development based on public investment in social infrastructure and human resources is a prerequisite for the longterm socio-economic development of Latvia.

\section{Conclusions}

Improving quality of life is the most important area of social and economic policy. The level and quality of life are interconnected. The standard of living characterizes the socio-economic outcomes of social development.

The relatively high ranking of Latvia in the world indices associated with the development of human capital does not reflect the real situation with regard to the quality of life and preservation of human resources in Latvia.

Preservation of human resources of Latvia depends on the quality of life of its population. A decline in living standards for the population of Latvia in the period of economic crisis from 2008-2011 led to mass emigration of its citizens to the more prosperous countries of Western Europe.

Increasing the country's output after the crisis is impossible without changing the existing socioeconomic policies and infrastructure of the Latvian national economy 
In modern Latvia, the most urgent socio-economic problems related to improving the quality of life are employment, strengthening the social protection of the population, and the fight against poverty.

\section{References}

Astapov, K. (2006). Стратегия развития в постиндустриальной экономике [Development strategy in the post-industrial economy]. Мировая экономика и международные отночения [World Economy and International Relations], 2, 57-65.

Becker, G. (1993). Human capital. A Theoretical and Empirical Analysis, with Special Reference to Education (3rd ed.). Chicago, IL: The University of Chicago Press.

Ben-Porath, Y. (1967). The production of Human Capital and Life Cycle of Earnings. Journal of Political Economy, 75 (4), 352-365.

Białowolski, P., Czapiński, J., Grabowska, J., Kotowska, I. E., Panek, T., Strzelecki, P., Węziak-Białowolska, D. (2011). Household Living Conditions. Social Diagnosis 2011. Contemporary Economics [Special Issue], 5 (3), 50-112.

Czapiński, J. (2001). Szczęście - złudzenie czy konieczność? Cebulowa teoria szczęścia w świetle nowych danych empirycznych. [Happiness is an illusion or necessity? An 'Onion' Theory of Happiness in the light of new empiric data] In M. Kofta, T. Szustrowa (Eds.), Złudzenia, które pozwalaja żyć [Delusions, which allow you to live]. (2nd ed.). (pp. 266306). Warszawa: Wydawnictwo Naukowe PWN.

Czapiński, J. (2004). Psychologiczne teorie szczęścia. [Psychological theories of happiness] In J. Czapiński (Ed.), Psychologia pozytywna [Positive psychology]. (pp. 51-103). Warszawa: Wydawnictwo Naukowe PWN.

Czapiński, J. (2011a). Dynamika dobrostanu psychicznego: rola „atraktora szczęścia” i wydarzeń życiowych. [The dynamics of psychological wellbeing: the role of „attractor of happiness” and life events] In D. Doliński, W. Błaszczak (Ed.), Dynamika emocji. Teoria i praktyka [The dynamics of emotion. Theory and practice]. (pp. 283-302). Warszawa: Wydawnictwo Naukowe PWN.

Czapiński, J. (2011b). Summary. Social Diagnosis 2011. Contemporary Economics [Special issue], 5 (3), 262-285.
Czapiński, J., Sułek, A., Szumlicz, T. (2011). Individual Quality of Life. Social Diagnosis 2011. Contemporary Economics [Special issue], 5 (3), 113-187.

Dictionary. (2001). Social policy, living standards and quality of life.

Domański, R. (2010). Kapitał ludzki, PWN Biznes.

Eurostat. (2011) People at risk of poverty or social exclusion by NUTS 2 regions. Retrieved from http://appsso.eurostat.ec.europa.eu/nui/show. do?dataset=ilc_peps11\&lang=en\#

Quality of life. (1995). In Encyclopedic Dictionary of Sociology. (n.d.)

United Nations Development Programme. Human Development Report. (2013). The Rise of the South: Human Progress in a Diverse World. New York, NY. Retrieved from http://hdr.undp.org/en/ media/HDR2013_EN_Summary.pdf

n. a. (2011, August 29). In Riga, the number of poor people has been growing. Retrieved from http://www. mixnews.lv/ru/economics/news/2011-08-29/74315

Krochmal, J., \& Staniewski, M. (2010). Barriers of the Human Capital Shaping. Contemporary Economics, 4 (4), 231-248.

Mincer, J. (1975). Schooling, experience and earnings. New York, NY: Columbia University Press.

Mosyakin, A. (2012, March 26). В Латвии сейчас самьй низкий в ее истории уровень рождаемости [Currently, Latviahas thelowestbirth rate in its history]. Retrieved from http://www. bb.lv/bb/LV/7982/

Czapiński, J., \& Panek, T. (2011). Social Exclusion. Social Diagnosis 2011. Contemporary Economics [Special issue, 5 (3), 242-261.

Panek, T. (2011). Ubóstwo, wykluczenie społeczne i nierówności. Teoria i praktyka pomiaru [Poverty, social exclusion and inequality. Theory and practice of measurement]. SGH: Warszawa.

International Living. (2010). Quality of Life Index. Retrieved from http://www1.internationalliving. com/qofl2010/

Solovov, A. (2009). Составляющие интеллектуального капитала: человеческий капитал [Building blocks of intellectual capital: human capital]. Экономические науки [Economics], 3 (52), 106-109.

Schultz, T. (1971). Investment in Human Capital. The Role of Education and of Research. New York, NY: Free Press. 
Sianesi, B., \& Van Reenen, J. (2003). The Returns to Education: Macroeconomics. Journal of Economic Surveys, 17 (2), 157-200.

Staniewski, M. W. (2011). Management of Human Resources in the Aspect of Innovativeness. Contemporary Economics, 5 (1), 84-91.

State Regional Development Agency. (2008). Trends in social and economic development of cities in Latvia. Retrieved from http:/www.vraa.gov.lv/uploads/ documents/petnieciba/petijumi/Petijums_Latvijas\%20pilsetu\%20sociali\%20ekonomiskas\%20attistibas\%20tendences1.pdf

Subbeto, A. I. (1994). Управление качеством жизни и выживаемость человека [Quality management of life and survival of a man]. Standards and Quality, 1, 63-65.

Tnurow, L. (1970). Investment in Human Capital. Belmont, CA: Wadsworth Publishing Company. 
